\title{
Acidic and basic fibroblast growth factor expression levels in cervical cancer and their effects on tumor cell proliferation
}

\author{
Q.H. Zhang ${ }^{1 *}$, P. Xu ${ }^{2 *}$, Y.X. $\mathrm{Lu}^{3}$ and H.T. Dou ${ }^{1}$ \\ ${ }^{1}$ Department of Gynecology, Central Hospital of Zibo in Shandong, \\ Shandong, China \\ ${ }^{2}$ Department of Gynecology, \\ People's Hospital of ZhangQiu in Shandong Province, Shandong, China \\ ${ }^{3}$ Department of Gynecology Three Ward, People's Hospital of Linyi City, \\ Shandong, China \\ *These authors contributed equally to this study. \\ Corresponding author: H.T. Dou \\ E-mail: douhongtaohtg@sina.com
}

Genet. Mol. Res. 15 (4): gmr15049043

Received July 29, 2016

Accepted October 20, 2016

Published December 2, 2016

DOI http://dx.doi.org/10.4238/gmr15049043

Copyright (C) 2016 The Authors. This is an open-access article distributed under the terms of the Creative Commons Attribution ShareAlike (CC BY-SA) 4.0 License.

\begin{abstract}
Fibroblast growth factors (FGFs) play important roles in angiogenesis, wound healing, embryonic development, and endocrine signaling pathways. Increasingly, recent studies have reported aberrant FGF expression in various malignancies. However, the involvement of FGFs in cervical carcinoma pathogenesis remains unclear. We aimed to investigate expression of acidic (aFGF) and basic FGF (bFGF) in patients with this disease, and assess their effects on cervical cancer cell proliferation. Twenty cervical cancer patients and 10 cervical intraepithelial neoplasia (CIN) patients were recruited, and 10 cancerfree individuals were included as controls. Reverse transcription-
\end{abstract}


polymerase chain reaction and western blotting were employed to detect FGF mRNA and protein levels, respectively. Furthermore, HeLa cells were treated with FGFs and subjected to thiazolyl blue tetrazolium bromide assays to quantify proliferation. Compared with $\mathrm{CIN}$ and normal cervical tissues, aFGF and bFGF mRNA and protein levels were significantly elevated in cervical carcinomas $(\mathrm{P}<0.05)$. CIN tissues exhibited higher expression of these FGFs than normal tissues $(\mathrm{P}<0.05)$. Moreover, their mRNA levels were increased in advanced cancer stages $(\mathrm{P}<0.05)$, although no significant difference was detected between tumors of different differentiation grades in this regard $(\mathrm{P}>0.05)$. HeLa cell proliferation increased in an aFGF- and bFGF-dose-dependent manner $(\mathrm{P}<0.05)$, the latter exerting a more potent proliferative influence, with its effect peaking at $75 \mathrm{ng} / \mathrm{mL}$. aFGF and bFGF were highly expressed in cervical cancer tissues and their levels positively correlated with clinical stage. Both facilitate proliferation of cervical carcinoma cells and are implicated in cancer pathogenesis and progression.

Key words: Cervical carcinoma; aFGF; bFGF; Expression profile; Proliferation; Cancer pathogenesis and progression

\section{INTRODUCTION}

The cervix is the most common site of gynecologic diseases with a young age at onset (Ma et al., 2015a). Persistent acute cervical inflammation may develop into chronic cervical disease, which can lead to infertility and severe effects on health (Gaydos et al., 2009). Various chronic diseases, such as cervical erosion, polyps, and mucositis, frequently result in cervical intraepithelial neoplasia (CIN) or even cervical cancer (Rebolj et al., 2012; Zhu et al., 2013). Research has indicated that several factors, including oncogenes and tumorsuppressor genes, cell apoptosis, and angiogenesis, underlie the occurrence, progression, and malignant transformation of benign hyperplasias (Granados López and López, 2014; Rybicki et al., 2016). Cervical cancer is the most common female malignancy in developing countries, and its incidence has rapidly increased in people under the age of 35 years (Schiffman et al., 2011). With infiltration/metastasis occurring at a very early stage, cervical cancer has a relatively unfavorable prognosis and severely affects women's health.

Fibroblast growth factor (FGF) was first identified in the 1940s, and was purified in 1974 from bovine pituitary glands (Fessler et al., 2015; Huat et al., 2015a). All members of the FGF family share certain similarities but are distinguished by unique features. As a facilitator of cell division, acidic FGF (aFGF) is a potent promoter of cell proliferation and differentiation (Zhang et al., 2013). Basic FGF (bFGF) principally acts on mesoderm- and neuroectoderm-derived cells and can also function as a powerful cell division factor. In most analyses of bioactivity, bFGF demonstrates greater potency than aFGF (Huat et al., 2015b; Nguyen et al., 2015). FGFs, including these acidic and basic subtypes, exhibit a wide range of biological activities. Human aFGF and bFGF proteins are both composed of 154 amino acids, have the same receptor, and share over 55\% sequence homology (Zhao et al., 2012; Dai et al., 2014). Under the no-diseased state, bFGF exerts stronger effects than aFGF, both of

Genetics and Molecular Research 15 (4): gmr15049043 
which are widely distributed over multiple tissues, and can facilitate cell growth, proliferation, and differentiation by binding to their receptor (Lee et al., 2011). FGF receptors consist of an extracellular ligand domain (composed of three immunoglobulin-like domains), a single transmembrane helix domain, and an intracellular domain with tyrosine kinase activity. Previous studies have determined the expression of aFGF, bFGF, and their receptors in various malignancies, including breast, ovarian, prostate, gall bladder, and endometrial cancers, and pancreatic and esophageal carcinomas (Zhang et al., 2004; Lin et al., 2011).

Although FGF signaling is known to drive tumorigenesis in certain contexts (Billottet et al., 2004; Tiong et al., 2013), it may play a tumor suppressive role in other situations (Ricol et al., 1999). A number of studies have reported increased FGF levels in cervical cancer (Sliutz et al., 1995; Cheng et al., 2012; Chu et al., 2014); however, the connection between FGF signaling and the progression of this malignancy remains unclear. In this study, we measured aFGF and bFGF expression levels in tumor tissues from cervical cancer patients attending our hospital by reverse transcription-polymerase chain reaction (RT-PCR). We also evaluated the effect of FGF on the proliferation of cultured cervical cancer cells by thiazolyl blue tetrazolium bromide (MTT) assay.

\section{MATERIAL AND METHODS}

\section{General information}

A total of 20 cervical cancer patients (including 12 cases of squamous cell carcinoma and 8 of adenocarcinoma) having undergone surgery between January 2014 and January 2015 at the Central Hospital of Zibo in Shandong were recruited for this study. According to the International Federation of Gynecology and Obstetrics grading scale, there were five, nine, five, and one patient(s) at stage I, II, III, and IV, respectively. Eleven, seven, and two patients exhibited high, moderate, and low tumor differentiation, respectively. Patient ages ranged from 19-62 years (average age of $43.1 \pm 6.2$ years). All cervical cancer samples collected during biopsy were kept at $-70^{\circ} \mathrm{C}$ until needed. None of the patients had received radiotherapy or chemotherapy prior to participation in this study.

A further 10 patients (28-55 years of age, with an average of $40.8 \pm 5.3$ years) with hysteromyoma or adenomyosis were selected from our hospital. A total of $10 \mathrm{CIN}$ patients (20-58 years of age, with an average of $40.1 \pm 5.2$ years, including three, four, and three patients at stage I, II, and III, respectively) were also enrolled. There were no significant differences regarding age between the patient groups.

The current experimental protocol was approved by the Ethics Committee of the Central Hospital of Zibo, Zibo, China, before commencing the study. All patients and healthy volunteers gave their written consent for and approval of this study.

\section{Cells and reagents}

HeLa human cervical cancer cells were obtained from the Cellular Biology Department of the Chinese Medical University, Shenyang, China. aFGF, bFGF, and $\beta$-actin RT-PCR test kits were purchased from TaKaRa Bio (Kusatsu, Japan). A PTC-100 PCR thermal cycler was purchased from Bio-Rad (Hercules, CA, USA). TRIzol Reagent was purchased from Gibco BRL (Grand Island, NY, USA). aFGF, bFGF, RPMI-1640 culture medium, and MTT reagent were obtained from Sigma-Aldrich (Carlsbad, CA, USA).

Genetics and Molecular Research 15 (4): gmr15049043 


\section{RT-PCR}

Total RNA was extracted from cervical tissues using TRIzol Reagent, and its concentration calculated by measuring the 260/280 nm absorbance ratio. RNA (200 ng in $2 \mu \mathrm{L}$ ) was then used as a template to synthesize complementary DNA (cDNA) in a $20-\mu \mathrm{L}$ reaction using $1 \mu \mathrm{L}$ poly(A) tail-specific primers. Subsequently, this cDNA $(3 \mu \mathrm{L})$ was used as a template for PCR amplification using $1 \mu \mathrm{L}$ specific primers (Table 1 ) and $0.2 \mu \mathrm{L}$ DNA polymerase under the following conditions: $94^{\circ} \mathrm{C}$ pre-denaturation for $40 \mathrm{~s}$, followed by 30 cycles, each of which comprised $94^{\circ} \mathrm{C}$ denaturation for $40 \mathrm{~s}, 56^{\circ} \mathrm{C}$ annealing for $60 \mathrm{~s}$, and $72^{\circ} \mathrm{C}$ elongation for $60 \mathrm{~s}$, before a final $72^{\circ} \mathrm{C}$ elongation for 5 min. PCR products were separated by agarose gel electrophoresis and analyzed with Quantity One version 4.6.9 (Bio-Rad). $\beta$-actin was used as an internal reference. The optical density of each band was measured and ratios calculated to quantify relative expression levels.

Table 1. Sequences of primers used in this study.

\begin{tabular}{l|l|l}
\hline Target & Sense strand $\left(5^{\prime}-3^{\prime}\right)$ & Anti-sense strand (5'-3') \\
\hline aFGF & AAATCACCACCTTCACAGCC & GTTGTAATGGTTCTCCTCCAGC \\
\hline bFGF & ATGGCAGCCGGGAGCATCACC & CACACACTCCTTTGATAGACACAA \\
\hline$\beta$-actin & GAA ACTACCTTCAACTCCATC & CTAGAAGCATTTGCGGTGGACGATGGAGGGGCC \\
\hline
\end{tabular}

$\mathrm{aFGF}=$ acidic fibroblast growth factor, $\mathrm{bFGF}=$ basic fibroblast growth factor.

\section{Western blotting}

Cervical tissues were mixed with protein lysis buffer and centrifuged at $1200 \mathrm{rpm}$ for $20 \mathrm{~min}$. The supernatants were then recovered and mixed with western blotting buffer. Proteins (40 mg per lane) were separated by $8 \%$ sodium dodecyl sulfate-polyacrylamide gel electrophoresis and transferred to a polyvinylidene fluoride membrane. After blocking with nonfat milk solution at room temperature for $1 \mathrm{~h}$, the membrane was incubated with mouse anti-human aFGF (diluted 1:200), mouse anti-human bFGF (1:200), and rabbit anti-human $\beta$-actin (1:500) antibodies in phosphate-buffered saline-Tween 20 at $4{ }^{\circ} \mathrm{C}$ overnight. The membrane was then washed three times with Tris-buffered saline-Tween 20 (TBST; 5 min per wash), and incubated with rabbit anti-mouse immunoglobulin G antibody (1:2000) at room temperature for $1 \mathrm{~h}$. After rinsing in TBST, chromogenic substrates trimethylbenzene and $\mathrm{H}_{2} \mathrm{O}_{2}(2 \mathrm{~mL}$ each) were added to visualize protein bands, which were scanned and analyzed with the Quantity One software to calculate optical density.

\section{Cell culture}

For routine culture, HeLa human cervical cancer cells were maintained on RPMI1640 medium at $37^{\circ} \mathrm{C}$ in a humidified chamber containing $5 \% \mathrm{CO}_{2}$.

\section{Cell treatment}

HeLa cells in the log phase of growth were counted and seeded on a culture plate containing RPMI-1640 medium and 2\% fetal bovine serum (FBS). After being cultured overnight, cells were transferred to Dulbecco's modified Eagle's medium containing 10\% FBS (for experimental treatment cultures). $\operatorname{aFGF}(0.3,0.6$, and $1.2 \mathrm{mg} / \mathrm{mL})$ or bFGF $(50,75$, and 100 $\mathrm{ng} / \mathrm{mL}$ ) was then added to the culture plate. Negative control cells were cultured in parallel.

Genetics and Molecular Research 15 (4): gmr15049043 


\section{MTT assay}

An MTT assay was used to assess the viability of HeLa cells 24 and $48 \mathrm{~h}$ after treatment with different concentrations of aFGF or bFGF. First, MTT solution $(20 \mu \mathrm{L})$ was added to the culture medium in each well to a final concentration of $5 \mathrm{mg} / \mathrm{mL}$, and incubated with cells at $37^{\circ} \mathrm{C}$ for $4 \mathrm{~h}$. Then, the reaction was terminated by adding $150 \mu \mathrm{L}$ dimethyl sulfoxide to dissolve the formazan product. The absorbance of each well was tested at $570 \mathrm{~nm}$ using a microplate reader. Results for each treatment group were based on at least 10 wells.

\section{Statistical analysis}

SPSS 17.0 (SPSS Inc., Chicago, IL, USA) was used to analyze all data, which are reported as means \pm standard deviations. Quantitative analysis of immunoblot bands was carried out using the Image Total Tech software (Pharmacia, Piscataway, NJ, USA). Analysis of variance was used for multiple-group comparisons, followed by the least significant difference test for pairs of groups. P values less than 0.05 were considered statistically significant.

\section{RESULTS}

\section{Expression of aFGF and bFGF mRNA in cervical tissues}

We used RT-PCR to determine aFGF and bFGF mRNA expression profiles in cervical cancer, $\mathrm{CIN}$, and normal cervical tissues. aFGF and bFGF levels were significantly elevated in cervical cancer tissues compared to normal cervical and CIN tissues $(\mathrm{P}<0.05$, Table 2). Moreover, expression of these FGFs positively correlated with cervical cancer clinical stage $(\mathrm{P}<0.05)$. Differentiation grade, however, had no significant effect on FGF expression ( $\mathrm{P}$ $>0.05)$. Furthermore, CIN specimens exhibited higher aFGF and bFGF mRNA levels than normal tissues $(\mathrm{P}<0.05$, Table 2$)$.

Table 2. Acidic and basic fibroblast growth factor mRNA levels in cervical cancer, cervical intraepithelial neoplasia, and normal cervical tissues.

\begin{tabular}{l|c|c|c}
\hline Group & $\mathrm{N}$ & aFGF mRNA & bFGF mRNA \\
\hline Cervical cancer & 20 & $1.225 \pm 0.059^{\mathrm{a}, \mathrm{b}}$ & $1.321 \pm 0.086^{\mathrm{a}, \mathrm{b}}$ \\
\hline Clinical stage & & & $0.989 \pm 0.102$ \\
\hline I & 5 & $0.965 \pm 0.048$ & $1.168 \pm 0.045^{\mathrm{c}}$ \\
\hline II & 9 & $1.032 \pm 0.076^{\mathrm{c}}$ & $1.356 \pm 0.116^{\mathrm{c}, \mathrm{d}}$ \\
\hline III & 5 & $1.278 \pm 0.118^{\mathrm{c}, \mathrm{d}}$ & $1.397 \pm 0.132^{\mathrm{c}, \mathrm{d}, \mathrm{e}}$ \\
\hline IV & 1 & & $1.236 \pm 0.087$ \\
\hline Differentiation grade & & $1.178 \pm 0.112$ & $1.295 \pm 0.106$ \\
\hline High & 11 & $1.138 \pm 0.126$ & $1.328 \pm 0.097$ \\
\hline Moderate & 7 & $1.192 \pm 0.098$ & $0.789 \pm 0.046^{\mathrm{b}}$ \\
\hline Low & 2 & $0.767 \pm 0.033^{\mathrm{b}}$ & $0.656 \pm 0.014$ \\
\hline CIN tissue & 10 & $0.643 \pm 0.026$ & \\
\hline
\end{tabular}

aFGF = acidic fibroblast growth factor, bFGF = basic fibroblast growth factor, CIN = cervical intraepithelial neoplasia. ${ }^{a} \mathrm{P}<0.05$ compared to $\mathrm{CIN}$ tissue; ${ }^{b} \mathrm{P}<0.05$ compared to normal cervical tissue; ${ }^{\text {c }} \mathrm{P}<0.05$ compared to stage I; ${ }^{\mathrm{P}}<0.05$ compared to stage II; ${ }^{\mathrm{e}} \mathrm{P}<0.05$ compared to stage III.

Genetics and Molecular Research 15 (4): gmr15049043 


\section{aFGF and bFGF protein expression}

Western blotting was employed in order to estimate the expression of aFGF and bFGF proteins in each cervical tissue type. aFGF and bFGF protein levels were significantly increased in cervical cancer tissues compared to CIN and normal cervical tissues $(P<0.05)$. In addition, expression of these proteins in CIN specimens was also significantly higher than that observed in normal tissues $(\mathrm{P}<0.05$, Figures 1 and 2$)$.

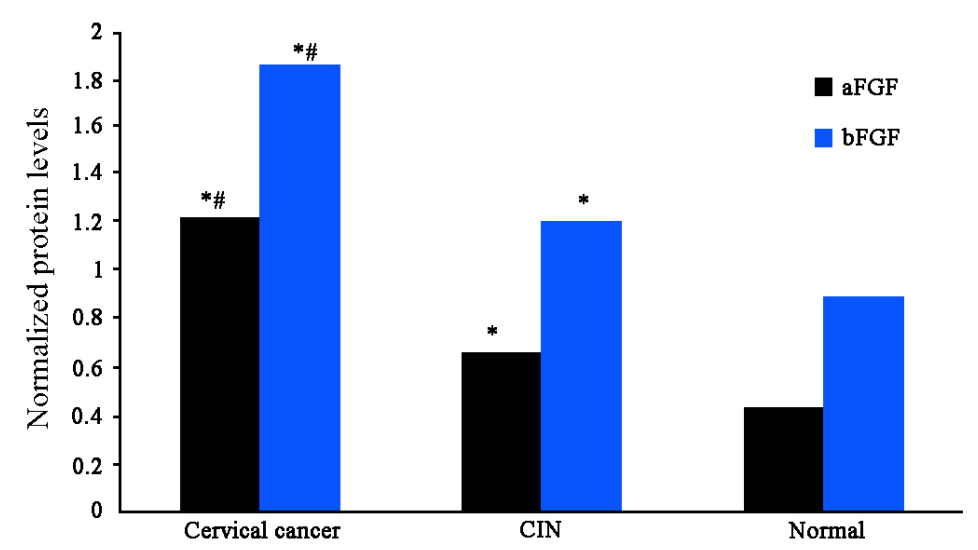

Figure 1. Protein levels of aFGF and bFGF in cervical cancer, CIN and normal cervical tissues. $* \mathrm{P}<0.05$ compared to $\mathrm{CIN}$ tissues; ${ }^{\#} \mathrm{P}<0.05$ compared to normal cervical tissues.

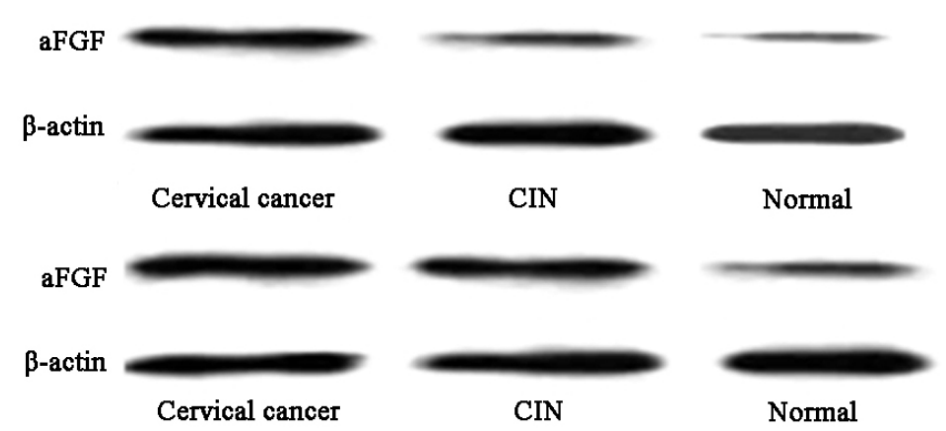

Figure 2. Western blotting bands showing aFGF and bFGF in cervical cancer, CIN and normal cervical tissues.

\section{HeLa cell proliferation following aFGF/bFGF treatment}

HeLa cells were treated with different concentrations of aFGF and bFGF in order to investigate the effect of these molecules on proliferation, as measured by MTT assay. With gradual increases in aFGF and bFGF concentration, cell viability increased significantly ( $\mathrm{P}$ $<0.05$, Table 3), corresponding to elevated cell number or metabolic activity. Compared to aFGF, bFGF exerted a significantly stronger effect on HeLa cells $(\mathrm{P}<0.05$, Table 3$)$, with proliferation peaking at a concentration of $75 \mathrm{ng} / \mathrm{mL}$. 
Table 3. HeLa cell proliferation following treatment with acidic and basic fibroblast growth factors.

\begin{tabular}{l|c|c|c|c}
\hline Treatment & \multicolumn{2}{|c|}{ OD value } & \multicolumn{2}{c}{ Proliferation ratio (\%) } \\
\hline $\mathrm{aFGF}(\mu \mathrm{g} / \mathrm{mL})$ & $24 \mathrm{~h}$ & $48 \mathrm{~h}$ & $24 \mathrm{~h}$ & $48 \mathrm{~h}$ \\
\hline 0 & $0.792 \pm 0.002$ & $0.801 \pm 0.003$ & 100 & 100 \\
\hline 0.3 & $0.724 \pm 0.017^{*}$ & $0.875 \pm 0.026^{*}$ & 102 & 118 \\
\hline 0.6 & $1.021 \pm 0.032^{*}$ & $1.076 \pm 0.044^{*}$ & 114 & 135 \\
\hline 1.2 & $1.131 \pm 0.041^{*}$ & $1.234 \pm 0.056^{*}$ & 136 & 156 \\
\hline $\mathrm{bFGF}(\mathrm{ng} / \mathrm{mL})$ & & & & \\
\hline 0 & $0.792 \pm 0.002$ & $0.800 \pm 0.003$ & 100 & 100 \\
\hline 50 & $1.012 \pm 0.007^{*}$ & $1.034 \pm 0.012^{*}$ & 122 & 131 \\
\hline 75 & $1.325 \pm 0.015^{*}$ & $1.523 \pm 0.029^{*}$ & 178 & 198 \\
\hline 100 & $1.323 \pm 0.027^{*}$ & $1.486 \pm 0.031^{*}$ & 169 & \\
\hline
\end{tabular}

$\mathrm{aFGF}=$ acidic fibroblast growth factor, $\mathrm{bFGF}=$ basic fibroblast growth factor, $\mathrm{OD}=$ optical density. $* \mathrm{P}<0.05$ compared to control group.

\section{DISCUSSION}

In this study, we recruited cervical cancer and CIN patients and individuals with normal cervices, showing aFGF and bFGF mRNA levels to be significantly elevated among cervical cancer sufferers compared to the other groups examined. Moreover, aFGF and bFGF mRNA expression increased with cervical cancer clinical stage. No significant difference, however, was identified between cervical cancer tissues of different differentiation grades. Western blotting indicated that aFGF and bFGF protein expression was highest in cervical cancer specimens, followed by CIN and normal cervical tissues. Together, these results suggest that the genes encoding aFGF and bFGF are overexpressed in cervical cancer tissues, and that this closely correlates with the occurrence and progression of this disease. However, due to the limited numbers of patients included in the present study (a key limitation of this study), largecohort clinical studies are required to confirm these findings. Previous investigations have reported that aFGF and bFGF mRNA levels are significantly elevated in pancreatic cancer compared to normal tissues, with expression of bFGF being higher than that of aFGF, although not to a significant degree (Yamanaka et al., 1993; Walsh et al., 2008). One study of endometrial carcinoma found that both of these FGFs and the FGF receptors are overexpressed in such tumor tissues (Fujimoto et al., 1996). Similar patterns have also been observed in ovarian metastases derived from tumors of the small intestine (Facco et al., 1998). A number of reports have indicated that aFGF and bFGF are minimally expressed in a wide array of human tissues, and can regulate DNA synthesis and facilitate cell division. When cells undergo malignant transformation, however, aFGF and bFGF transcription is increased by the synergistic effects of various tumor-stimulating factors, facilitating the division and proliferation of tumor cells via autocrine or paracrine mechanisms (Ferreira et al., 2015; Ma et al., 2015b).

Here, we also employed HeLa cells as a model of cervical cancer, treating them with different concentrations of aFGF and bFGF and measuring subsequent proliferative activity. Raising the concentrations of aFGF and bFGF resulted in incremental increases in the cell proliferation ratio. Compared to aFGF, bFGF stimulated proliferation to a greater extent, with the strongest effect being recorded at a concentration of $75 \mathrm{ng} / \mathrm{mL}$. These results suggest that both aFGF and bFGF can enhance the proliferation of cervical cancer cells in a dosedependent manner ( $\mathrm{Li}$ et al., 1994). A previous study also found aFGF to be overexpressed in breast cancer tissues, accelerating the proliferation and differentiation of tumor cells, and facilitating cancer progression (Yoshimura et al., 1998), consistent with our results.

Genetics and Molecular Research 15 (4): gmr15049043 
In summary, both aFGF and bFGF were highly expressed in cervical cancer tissues. In tumors of higher clinical stages, the expression of these factors was further enhanced, suggesting that they play a role in facilitating cervical cancer cell proliferation. This study reveals the potential clinical utility of aFGF and bFGF in cervical cancer diagnosis and prognosis.

\section{Conflicts of interest}

The authors declare no conflict of interest.

\section{ACKNOWLEDGMENTS}

We thank the anonymous reviewers for reviewing this manuscript.

\section{REFERENCES}

Billottet C, Elkhatib N, Thiery JP and Jouanneau J (2004). Targets of fibroblast growth factor 1 (FGF-1) and FGF-2 signaling involved in the invasive and tumorigenic behavior of carcinoma cells. Mol. Biol. Cell 15: 4725-4734. http:// dx.doi.org/10.1091/mbc.E04-04-0336

Cheng YM, Chou CY, Hsu YC and Chen MJ (2012). Influence of HPV16 E6/7 on the expression of FGF2 and FGFR type B in cervical carcinogenesis. Reprod. Sci. 19: 580-586. http://dx.doi.org/10.1177/1933719111432874

Chu TY, Yang JT, Huang TH and Liu HW (2014). Crosstalk with cancer-associated fibroblasts increases the growth and radiation survival of cervical cancer cells. Radiat. Res. 181: 540-547. http://dx.doi.org/10.1667/RR13583.1

Dai X, Cai C, Xiao F, Xiong Y, et al. (2014). Identification of a novel aFGF-binding peptide with anti-tumor effect on breast cancer from phage display library. Biochem. Biophys. Res. Commun. 445: 795-801. http://dx.doi.org/10.1016/j. bbrc.2014.02.022

Facco C, La Rosa S, Dionigi A, Uccella S, et al. (1998). High expression of growth factors and growth factor receptors in ovarian metastases from ileal carcinoids: an immunohistochemical study of 2 cases. Arch. Pathol. Lab. Med. 122: 828-832.

Ferreira MM, Dewi RE and Heilshorn SC (2015). Microfluidic analysis of extracellular matrix-bFGF crosstalk on primary human myoblast chemoproliferation, chemokinesis, and chemotaxis. Integr. Biol. 7: 569-579. http://dx.doi. org/10.1039/C5IB00060B

Fessler E, Borovski T and Medema JP (2015). Endothelial cells induce cancer stem cell features in differentiated glioblastoma cells via bFGF. Mol. Cancer 14: 157.http://dx.doi.org/10.1186/s12943-015-0420-3

Fujimoto J, Hori M, Ichigo S and Tamaya T (1996). Expressions of the fibroblast growth factor family (FGF-1, -2 and -4) mRNA in endometrial cancers. Tumour Biol. 17: 226-233. http://dx.doi.org/10.1159/000217984

Gaydos C, Maldeis NE, Hardick A, Hardick J, et al. (2009). Mycoplasma genitalium as a contributor to the multiple etiologies of cervicitis in women attending sexually transmitted disease clinics. Sex. Transm. Dis. 36: 598-606. http:// dx.doi.org/10.1097/OLQ.0b013e3181b01948

Granados López AJ and López JA (2014). Multistep model of cervical cancer: participation of miRNAs and coding genes. Int. J. Mol. Sci. 15: 15700-15733.http://dx.doi.org/10.3390/ijms150915700

Huat TJ, Khan AA, Abdullah JM, Idris FM, et al. (2015a). MicroRNA expression profile of bone marrow mesenchymal stem cell-derived neural progenitor by microarray under the influence of EGF, bFGF and IGF-1. Genom. Data 5: 201-205.http://dx.doi.org/10.1016/j.gdata.2015.06.015

Huat TJ, Khan AA, Abdullah JM, Idris FM, et al. (2015b). MicroRNA expression profile of neural progenitor-like cells derived from rat bone marrow mesenchymal stem cells under the influence of IGF-1, bFGF and EGF. Int. J. Mol. Sci. 16: 9693-9718. http://dx.doi.org/10.3390/ijms16059693

Lee M, Kang Y, Suk K, Schwab C, et al. (2011). Acidic fibroblast growth factor (FGF) potentiates glial-mediated neurotoxicity by activating FGFR2 IIIb protein. J. Biol. Chem. 286: 41230-41245. http://dx.doi.org/10.1074/jbc. M111.270470

Li D, Bell J, Brown A and Berry CL (1994). The observation of angiogenin and basic fibroblast growth factor gene expression in human colonic adenocarcinomas, gastric adenocarcinomas, and hepatocellular carcinomas. J. Pathol. 172: 171-175.http://dx.doi.org/10.1002/path.1711720203

Genetics and Molecular Research 15 (4): gmr15049043 
Lin YL, Kuo HS, Lo MJ, Tsai MJ, et al. (2011). Treatment with nerve grafts and aFGF attenuates allodynia caused by cervical root transection injuries. Restor. Neurol. Neurosci. 29: 265-274.

Ma J, Kan Y, Zhang A, Lei Y, et al. (2015a). Female sexual dysfunction in women with non-malignant cervical diseases: a study from an urban Chinese sample. PLoS One 10: e0141004.http://dx.doi.org/10.1371/journal.pone.0141004

Ma SY, Feng ZQ, Lai RF and Yin ZD (2015b). Synergistic effect of RhBMP-2 and bFGF on ectopic osteogenesis in mice. Asian Pac. J. Trop. Med. 8: 53-59. http://dx.doi.org/10.1016/S1995-7645(14)60187-5

Nguyen TH, Paluck SJ, McGahran AJ and Maynard HD (2015). Poly(vinyl sulfonate) Facilitates bFGF-Induced Cell Proliferation. Biomacromolecules 16: 2684-2692. http://dx.doi.org/10.1021/acs.biomac.5b00557

Rebolj M, Helmerhorst T, Habbema D, Looman C, et al. (2012). Risk of cervical cancer after completed post-treatment follow-up of cervical intraepithelial neoplasia: population based cohort study. BMJ 345: e6855. http://dx.doi. org/10.1136/bmj.e6855

Ricol D, Cappellen D, El Marjou A, Gil-Diez-de-Medina S, et al. (1999). Tumour suppressive properties of fibroblast growth factor receptor 2-IIIb in human bladder cancer. Oncogene 18: 7234-7243. http://dx.doi.org/10.1038/ sj.onc. 1203186

Rybicki BA, Rundle A, Kryvenko ON, Mitrache N, et al. (2016). Methylation in benign prostate and risk of disease progression in men subsequently diagnosed with prostate cancer. Int. J. Cancer 138: 2884-2893. http://dx.doi. org/10.1002/ijc. 30038

Schiffman M, Wentzensen N, Wacholder S, Kinney W, et al. (2011). Human papillomavirus testing in the prevention of cervical cancer. J. Natl. Cancer Inst. 103: 368-383. http://dx.doi.org/10.1093/jnci/djq562

Sliutz G, Tempfer C, Obermair A, Reinthaller A, et al. (1995). Serum evaluation of basic fibroblast growth factor in cervical cancer patients. Cancer Lett. 94: 227-231. http://dx.doi.org/10.1016/0304-3835(95)03853-O

Tiong KH, Mah LY and Leong CO (2013). Functional roles of fibroblast growth factor receptors (FGFRs) signaling in human cancers. Apoptosis 18: 1447-1468. http://dx.doi.org/10.1007/s10495-013-0886-7

Walsh CT, Wei Y, Wientjes MG and Au JL (2008). Quantitative image analysis of intra-tumoral bFGF level as a molecular marker of paclitaxel resistance. J. Transl. Med. 6: 4. http://dx.doi.org/10.1186/1479-5876-6-4

Yamanaka Y, Friess H, Buchler M, Beger HG, et al. (1993). Overexpression of acidic and basic fibroblast growth factors in human pancreatic cancer correlates with advanced tumor stage. Cancer Res. 53: 5289-5296.

Yoshimura N, Sano H, Hashiramoto A, Yamada R, et al. (1998). The expression and localization of fibroblast growth factor-1 (FGF-1) and FGF receptor-1 (FGFR-1) in human breast cancer. Clin. Immunol. Immunopathol. 89: 28-34. http://dx.doi.org/10.1006/clin.1998.4551

Zhang X, Wang Y, Gao Y, Liu X, et al. (2013). Maintenance of high proliferation and multipotent potential of human hair follicle-derived mesenchymal stem cells by growth factors. Int. J. Mol. Med. 31: 913-921.

Zhang Y, Guo KJ, Shang H, Wang YJ, et al. (2004). Expression of aFGF, bFGF, and FGFR1 in ovarian epithelial neoplasm. Chin. Med. J. (Engl.) 117: 601-603.

Zhao YZ, Lu CT, Li XK, Tang QQ, et al. (2012). Improving the cardio protective effect of aFGF in ischemic myocardium with ultrasound-mediated cavitation of heparin modified microbubbles: preliminary experiment. J. Drug Target. 20: 623-631. http://dx.doi.org/10.3109/1061186X.2012.702771

Zhu T, Chen Z, Xia Q, Jiang S, et al. (2013). A suppository for treating cervical erosion and its preparation method. Clin. Exp. Obstet. Gynecol. 40: 361-366. 